\title{
Place-based Instruction in Archives: Our Pedagogical Roots
}

\author{
By Carrie Schwier and Carey Beam
}

Carrie Schwier is an outreach and public service archivist at IU Libraries' University Archives.

She collaborates with teaching faculty to design and implement primary-source based instruction sessions and assignments. She received her MLS from Indiana University and also holds an MA and a BA in art history.

Carey Beam is an assistant librarian and the director of the Indiana University Libraries' Wylie House Museum and Morton C. Bradley, Jr. Education Center. She facilitates the use of the museum's archival and object collections to support the university curriculum. She earned both an MLS and a BA in Sociology from Indiana University.

Carrie Schwier

Herman B Wells Library E460

1320 E. $10^{\text {th }}$ St.

Bloomington, Indiana 47405

U.S.A.

clschwie@indiana.edu

Carey Beam

MCB, Jr. Education Center

317 E. Second St.

Bloomington, Indiana 47401

U.S.A.

crbeam@indiana.edu 


\begin{abstract}
Archival instruction has undergone an evolution of growth over the past several years in the United States. As archivists at colleges and universities increase their instructional roles, it is to the benefit of students and instructional partners that archivists inform themselves of relevant learning theories that can influence teaching with campus heritage collections. Place-Based Education (PBE) leverages local environments, communities, resources, and people into immersive learning opportunities. It prioritizes engagement and authentic interactions and offers instructional archivists the opportunity to harness the power of place inside the classroom. This article provides an overview of the pedagogical landscape in archives, an introduction to placebased teaching and learning, and case studies from courses at Indiana University.
\end{abstract}

\title{
Place-based Instruction in Archives: Our Pedagogical Roots
}

Public historians refer to Place-Based Education (PBE) as the "the power of place," folklorists “place-making," museums "place-based learning." Within the archival community, this concept has yet to be articulated, but it is evident in the use of university collections. In July 2016 The Chronicle of Higher Education published the article "Why a College Should Teach its Own History.” The author Corey Ryan Earle, a visiting lecturer at Cornell University, notes 
that teaching institutional history offers students a "unifying experience, creating a sense of community" which is "rare and difficult to create."1

Archival instruction has undergone an evolution of growth over the past several years in the United States. In addition to supporting content study, archivists are teaching research skills, archival intelligence, and primary source literacy competencies. Combining theory and case study, this article posits that it is important that archivists become familiar with the pedagogical roots which they use and from which they can be more effective teachers in the archives. In particular, the authors propose that archivists working in institutions of higher education consider the value and strengths of place-based education to enhance instructional impact through campus collections. As archivists at colleges and universities increase their instructional roles, they have the potential to harness the power of place and campus heritage inside the classroom. This article provides an overview of the pedagogical landscape in archives, an introduction to place-based teaching and learning, and case studies from courses at Indiana University.

The case studies demonstrate how the authors (a university archivist and special collections librarian at a campus historic house museum) used place-based teaching to intentionally draw out connections with the past. This approach allowed students to identify with Indiana University through former students. The voices found in the diaries, scrapbooks, letters, and photographs in the university collections were their predecessors and perhaps even their ancestors. The artifacts are evidence of the lives of past students who had similar experiences, who were developing their own personal identities, and who occupied the same campus spaces

\footnotetext{
${ }^{1}$ EARLE Corey Ryan, "Why a College Should Teach its Own History," in The Chronicle of Higher Education, July 20, 2016 at https://www.chronicle.com/article/Why-a-College-Should-Teach-Its/237166- Accessed 14 January 2018.
} 
that students experience today. Through this shared experience across time, the historical record becomes all the more real. Place-based education fosters a sense of student curiosity about the distant past, helps students draw parallels between their experiences and that of their predecessors, and then allows them to situate those observations within the context of the present time and culture.

\section{The Pedagogical Landscape}

As Magia Krause reported in The American Archivist in 2008, 66 percent of repositories reported offering more than five instruction sessions per year. $75 \%$ of these were targeted at undergraduates. Despite this prevalence, she also noted that the majority of archivists are "selftaught" instructors. ${ }^{2}$ Similarly, Kate Theimer notes that while instruction "often benefits from a background in pedagogy, most archivists lack any formal training... and simply forge ahead as best they can." ${ }^{3}$ With so many archivists teaching, it is to the benefit of students and instructional partners that they inform themselves of the dominant learning theories. Teaching archivists are already, consciously or not, employing teaching methods. Knowledge of the histories of those methods, their strengths and weaknesses, and the learning objectives best suited to them will strengthen the archivists' role as educators and potentially enhance their standing within their institutions.

Thankfully, over the last 20 years much has been written about the value of integrating primary sources into the classroom. Most of the archival literature has rightly focused on four

\footnotetext{
${ }^{2}$ KRAUSE Magia G., "Learning in the Archives: A Report on Instructional Practices," in Journal of Archival Organization 6.4 (2008), 240-248.

3 THEIMER Kate, "Introduction," In Educational Programs: Innovative Practices for Archives and Special Collections, Lanham: Rowman and Littlefield, 2015, vii.
} 
main areas: establishing the role of the archivist in instruction ${ }^{4}$, pedagogical theory and defining

learning objectives, ${ }^{5}$ and assessing impact and learning outcomes. ${ }^{6}$ Furthermore, case studies

documenting what this looks like in practice are prevalent. ${ }^{7}$ Several authors cite the foundational

1998 Boyer Commission Report on Reinventing Undergraduate Education sponsored by the

\footnotetext{
${ }^{4}$ CARINI Peter, "Archivists as Educators: Integrating Primary Sources into the Curriculum," in Journal of Archival Organization 7.1-2 (2009), 41-50; KRAUSE Magia G., "“It Makes History Alive for Them:' The Role of Archivists and Special Collections Librarians in Instructing Undergraduates," in The Journal of Academic Librarianship 36. 5 (2010), 401-411; MORRIS Sammie L., CHUTE Tamar, and SWAIN Ellen, "Teaching with Archives: A Guide for Archivists, Librarians, and Educators," In Teaching with Primary Sources, edited by Christopher J. PROM and Lisa Janicke HINCHLIFFE, Chicago: Society of American Archivists, 2016, 69-136.

${ }^{5}$ YAKEL Elizabeth and TORRES Deborah A., "AI: Archival Intelligence and User Expertise,"in American Archivist 66. 1 (2003): 51-78; WEINER Sharon A., MORRIS Sammie, and MYKYTIUK Lawrence J., "Archival Literacy Competencies for Undergraduate History Majors," in American Archivist 78. 1 (2015): 154-80; CARINI Peter, "Information Literacy for Archives and Special Collections: Defining Outcomes," in Portal: Libraries and the Academy 16. 1 (January 2016): 191-206; ACRL SAA/RBMS Task Force on the Development of Guidelines for Primary Source Literacy, Guidelines for Primary Source Literacy- Final Version, at https://www2.archivists.org/sites/all/files/Guidelines\%20for\%20Primary\%20Souce\%20Literacy\%20\%20FinalVersion\%20-\%20Summer2017_0.pdf -Accessed 14 January 2019.
}

${ }^{6}$ DUFF Wendy M. and CHERRY Joan M., "Archival Orientation for Undergraduate Students: An Exploratory Study of Impact," in American Archivist 71. 2 (2008): 499-529; KRAUSE Magia, "Undergraduates in the Archives: Using an Assessment Rubric to Measure Learning," in American Archivist 73.2 (2010): 507-34; BAHDE Anne and SMEDBERG Heather, "Measuring the Magic: Assessment in the Special Collections and Archives Classroom," in RBM: A Journal of Rare Books, Manuscripts, and Cultural Heritage 13. 2 (2012): 152-74; DANIELS Morgan and YAKEL, "Uncovering Impact: The Influence of Archives on Student Learning," in Journal of Academic Librarianship 39.5 (2013): 414-422.

${ }^{7}$ ROCKENBACH Barbara. "Archives, Undergraduates, and Inquiry-Based Learning: Case Studies from Yale University Library." in American Archivist 74.1 (2011): 297-311; COX Richard J., ALCALA Janet Ceja, and BOWLER Leanne, "Archival Document Packets: A Teaching Module in Advocacy Training Using the Papers of Governor Dick Thornburgh." in American Archivist 75.2 (2012): 371-92; ANDERBERG Lindsay, "STEM Undergraduates and Archival Instruction: A Case Study at NYU Polytechnic School of Engineering." in American Archivist 78.2 (2015): 548-66; ROBB Jenny. "The Opper Project: Collaborating with Educators to Promote the Use of Editorial Cartoons in the Social Studies Classroom." in RBM: A Journal of Rare Books, Manuscripts and Cultural Heritage 10,.22 (2009): 70-94; BAHDE Anne. "Taking the Show on the Road: Special Collections Instruction in the Campus Classroom." in RBM: A Journal of Rare Books, Manuscripts and Cultural Heritage 12.2 (2011): 75-88.; FRUSCIANO Thomas, "Bridging Generations: Undergraduate Research Opportunities on the History of Women at Rutgers University," in Journal of Archival Organization 1.2 (2002): 77-88; NIMER Cory L., and DAINES J. Gordon III, "Teaching Undergraduates to Think Archivally." Iin Journal of Archival Organization 10. 1 (2012): 4-44; BAHDE Anne, "The History Labs: Integrating Primary Source Literacy Skills into a History Survey Course." in Journal of Archival Organization 11.3-4 (2013): 175-204; MITCHELL Eleanor, SEIDEN Peggy, and TARABA Suzy, eds. Past or Portal? Enhancing Undergraduate Learning through Special Collections and Archives -Chicago: Association of College and Research Libraries, 2012; BAHDE Anne, SMEDBERG Heather, and TAORMINA Mattie, in Using Primary Sources : Hands-on Instructional Exercises, Santa Barbara, CA, Libraries Unlimited, 2014; and THEIMER Kate, Educational Programs: Innovative Practices for Archives and Special Collections. Lanham: Rowman \& Littlefield Publishers, 2015. 
Carnegie Foundation, which outlined ten recommendations for "the radical reconstruction of undergraduate education at research universities." ${ }^{\prime 8}$ Of these, the recommendations calling for a focus on inquiry-based learning and involving students in the research process, pose obvious possibilities for use in archival instruction. As a result, archival literature has focused on this approach in addition to a related shift towards active-learning techniques. Interestingly though, the final recommendation to "Cultivate a Sense of Community" which calls for universities "to foster a community of learners" and "create a sense of place" is absent from discussion in our literature. ${ }^{9}$ While there are surely many methods used by instructional archivists, in the university archives setting, this is one method that is inextricable from what we do.

By no means a new concept, place is defined by rural and geographical sociologist Frank Vanclay as "'space' imbued with meaning....it is the coming together of the biophysical, social and spiritual worlds. Simply put, place is space that is special to someone." ${ }^{10}$ It is a recurrent theme across a wide range of disciplines. Within the context of the university, this concept of "place" translates to the built environment and greenspaces of our campus and local communities, to the historic figures and alumni associated with these spaces, and to the associated traditions and legends which give each their uniqueness.

Place-based education refers to teaching and learning that is rooted in what is local - the unique history, environment, culture, economy, literature, and art of a particular place. It is what

\footnotetext{
${ }^{8}$ Boyer Commission on Educating Undergraduates in the Research University, Stoney Brook, NY, Reinventing Undergraduate Education: A Blueprint for America's Research Universities, Stony Brook, NY: State University of New York, 1998, 1.

${ }_{9}^{9}$ Boyer Commission, Reinventing Undergraduate Education, 34.

${ }^{10}$ Making Sense of Place: Exploring Concepts and Expressions of Place through Different Senses and Lenses, edited by Frank VANCLAY, Mathew HIGGINS, and Adam BLACKSHAW, Canberra: National Museum of Australia Press, 2008, 3.
} 
teaching or instructional archivists most likely already do. Founded on the principle that linking students to their local environments and communities makes learning meaningful to their studies and their lives, place-based education inspires interest, motivates rigorous study, and encourages deeper inquiry. Ultimately, students engage in deeper inquiry and more meaningful learning.

\section{History, Relevance to Archives, and Primary Advantages of Place-based Learning:}

Using the local environment as a teaching tool stems from the work of early twentieth century American educator, John Dewey. His philosophy of education extolled the values of experiential learning, which promoted a hands-on, student-centered focus. Ideally, it placed learning in what Dewey referred to as "life terms" by using what is "already seen and felt and loved by learners." University archivists teaching with campus collections see it in the classroom when students recognize their favorite campus hangouts in historic photographs, when they identify with a student who wrote of homesickness in his diary more than a hundred years ago, or when they empathize with the students marching on campus for social justice just decades ago. More than likely, most teaching archivists have witnessed the intensity with which these connections can induce deep learning experiences. Curiosity is heightened, questions abound, and, on occasion, students pursue independent research as a result of lessons and assignments based off of campus archives.

When archivists teach with campus collections, they inevitably infuse their instruction and assignments with local history and culture. They immerse students in a sense of place by

\footnotetext{
${ }^{11}$ DEWEY John "The Child and the Curriculum," in John Dewey on Education: Selected writings, edited by R.D. Archambault, Chicago, IL: University of Chicago Press, 1902, 352-353.
} 
providing them with contextually familiar resources. Active-learning opportunities are embedded in archival instruction through the handling of primary materials, the evaluation of primary sources, and transcriptions exercises, to name just a few examples. Often, campus collections are used for course research projects or inspire art projects or performances. While campus collections may seem limited in scope, archivists should not underestimate their educational potential. Studies on place-based instruction reveal that students who learn from and about their local resources are able to cultivate the very sense of community encouraged by the Boyer report. There is a body of evidence to support the teaching practices most archivists already engage in. Knowing and leveraging the benefits of place-based education provides strategic teaching opportunities and methodological guidance as archivists design lessons and assignments.

While there are many documented advantages to this pedagogical approach, the three that are most relevant to university archives are: cultivating citizenship, acknowledging complexity, and being applicable to numerous disciplines. The first of these is citizenship: students will learn about their heritage and community (whether it be cultural, environmental, or academic) and will positively contribute to it. Place-based learning developed in the environmental science discipline. Educators took students "into the field" and as students became more familiar with the location of study, the more inclined they were to solve location-based problems. For example, in one case study noted by David Sobel and Gregory Smith, students who saw the effects of pollution in local bodies of water not only better understood the damage to wildlife and 
vegetation but were motivated to act by meeting with local government leaders and hosting educational forums for the public. ${ }^{12}$

When archivists expose students to campus collections they are cultivating campus citizenship. Providing students with unmediated sources gives them the opportunity to share the unique perspectives and knowledge they bring to the evaluation and analysis of these materials. They participate in the conversation relevant to the collections and their environment and history. The students' hypotheses, interpretations and synthesis of primary materials can be made explicit within the context of their roles within the campus community. This provides them with an opportunity to self-reflect about their use of those materials and their agency in creating new primary sources. They have the opportunity to contribute their perspective and voice to an understanding and interpretation of that artifact. Like the environmental studies students who act to solve local water pollution concerns, students who become familiar with their student history recognize that they are part of a community story to which they can positively contribute.

Another strength of place-based teaching and learning is that it acknowledges complexity. It makes explicit the many variables that contribute to place or community. Studying a particular location or archival record may appear relatively simple but has many implications. A broad understanding of place is inclusive of culture, gender, ethnicity, race and class as critical dimensions of our experience of the local. Similar complexities hold true for archival materials.

In 2017 the Primary Source Literacy Guidelines were published by the Joint task force of the Society of American Archivists and the Rare Books and Manuscripts Section of the Association

\footnotetext{
${ }^{12}$ SMITH Gregory A. and SOBEL David, Place- and Community-based Education in Schools (New York: Routledge, 2010), 43-58.
} 
of College and Research Libraries. ${ }^{13}$ While providing direction for instructional archivists they also underscored the complexity of primary sources. They provide direction as we navigate the intricacies of primary source instruction and assignment design. Primary source literacy overlaps and intersects with visual, digital, and information literacies, all of which are subject to the influence of dominant culture and narratives, socio-political forces, collective memory, historic interpretation, and individual perspectives. Rather than being burdened by complexities, placebased pedagogy acknowledges the strength of the interdependence between the critical theory and immersive, local learning. Critical inquiry is an advantage as students challenge the assumptions and practices taken for granted by the dominant culture in physical spaces as well as archival records.

The third strength of place-based instruction relevant to archivists is its successful incorporation into numerous disciplines, from the arts and humanities to the social and applied sciences. This broad disciplinary relevance makes it easily attributable to campus collections that also have instructional relevance in a wide variety of disciplines. Archivists leverage the interest that campus collections inspire in students to impart primary source literacy and research skills, regardless of the course subject. Indeed, a single collection, like a single place, can serve as a teaching tool for any number of courses. The collection content does not necessarily need to directly relate to the course but can act as a compelling hook for student interest and connection. Archivists also often successfully employ another strength associated with place-based learning by encouraging students to select the collection or artifact of interest to them for evaluation or research purposes. This student-centered approach provides evidence of deeper work quality that

\footnotetext{
13 ACRL SAA/RBMS Task Force on the Development of Guidelines for Primary Source Literacy, Guidelines for Primary Source Literacy- Final Version, at https://www2.archivists.org/sites/all/files/Guidelines\%20for\%20Primary\%20Souce\%20Literacy\%20\%20FinalVersion\%20-\%20Summer2017_0.pdf - Accessed on 14 January 2019.
} 
assumes greater meaning for students. It does so by building upon the key strength of placebased education - taking advantage of student interest and personal motivation.

Place-based education contributes to civic engagement and investment in local cultural and economic environments. It strengthens students' connections to their communities, their region, and the other people in those environments. If these are the broader implications for place-based teaching and learning, it is certainly likely that when students learn about their history and heritage through campus archives, they can create a strong and positive institutional identity.

\section{Primary Shortcoming or Achilles' heel of this Place-based Education}

As archivists consciously apply and leverage the strengths of any teaching method it is also important to be aware of its weaknesses. In this case, the very strength of place-based education is also its weakness. Researchers Eric Ball and Alice Lai point out that place-based pedagogies assume that the local is meaningful to students, but local or familiar does not necessarily mean it is significant to the student. ${ }^{14}$ There are students who find little connection to campus history and are uninspired, or even find alienation and pain in the primary source materials found in the collections. There are many potential reasons for this. Developmentally, student experiences are more self-serving than immersive, focusing on coursework and future plans more than on campus culture or school spirit. Perhaps they are commuter students, or nontraditional students with work and family obligations, or members of a minority student population who are not well represented in our collections, or only represented in instances of strife. Most importantly, as

${ }^{14}$ BALL Eric L. and LAI Alice, "Place-Based Pedagogy for the Arts and Humanities," in Pedagogy 6.2, (2006), 268. 
instructors we must be aware of the varied life experiences found in our classrooms, and strive to serve all.

In these cases where the school or its history holds little meaning for students, it is possible that the institution's primary sources may be an avenue to inspiring newfound campus interest or pride. The collections may shed light on previously unknown stories of students who were marginalized in the school's history. However, it is also likely that some students will simply never find the archival collections compelling, and it is important that teaching archivists are aware of this and watching for it. In these cases, the archivist's primary task is to foster connections and facilitate student engagement, perhaps by means of another, more fitting pedagogical methodology. When approaching historical evidence of discrimination or trauma in the classroom, we suggest that teaching archivists look for an additional framework such as affect theory to bolster their teaching. Authors such as Michalinos Zembylas eloquently discuss the teaching of "difficult knowledge" often found in our collections, and offers suggestions for the "conceptual, curricular, and pedagogical way out of dilemmas of representation...." 15 Again, it is always important to remain cognizant that no two learners are the same, and as teachers we often must use multiple pedagogical frames in any given session to best serve our students.

\section{Case Studies}

Established in 1820, Indiana University Bloomington is the main campus of a wider network that includes several regional campus sites throughout the state of Indiana and over 50,000 undergraduate and graduate students. In recent years, the University's Archives and its historic

\footnotetext{
${ }^{15}$ ZEMBYLAS, Michalinos, " Theorizing "Difficult Knowledge" in the Aftermath of the "Affective Turn": Implications for Curriculum and Pedagogy in Handling Traumatic Representations," in Curriculum Inquiry 44.3 (2015) at https://doi.org/10.1111/curi.12051. Accessed June 18, 2019.

${ }^{16}$ Hannah, X480 Student in post-course reflection, June 2018.
} 
Wylie House Museum have worked independently and collaboratively to increase their academic involvement in the campus curriculum. Rather than being limiting, the efforts have been successful, and the use of local campus collections at each repository is a compelling factor in student engagement and enriched learning opportunities. The collections embody a legacy of the students' campus community and heritage as well as providing fertile ground for reflection, skill development, creative production, community connection, and new contributions to the institutional narrative.

The instruction programs of both repositories have grown dramatically in the past five years to reach a wide swath of departments across the University. In 2017, the University Archives held over 80 separate sessions reaching over 1,200 students across over 20 departments. Similarly, the Wylie House provided 28 course sessions, reaching more than 500 students, spanning six departments. Departments served include American Studies, Art History, the School of Business, Central Eurasian Studies, Communication and Culture, Education, English, Folklore, Gender Studies, History, Latino Studies, the Media School, Music, the School of Art and Design, the School of Public Health, Spanish and Portuguese, and Theatre. Because of the nature of the collections, each instruction session utilizes primary sources with some sort of tie to the local, either through our campus spaces or an individual associated with the University. The following are two examples of this approach:

\section{Wylie House Museum, Indiana University Libraries}

The Wylie House Museum is the 1835 home of the first president of Indiana University and a small archival repository that is part of the campus Libraries. This historic property provides an opportunity to leverage the familiarity that will emerge through its archival collections and capitalize on an immersive experience in a historic building. Classes visit the Wylie House 
Museum for a variety of learning experiences, from archival research and primary source literacy lessons to material culture study and art inspiration. Two courses exemplify place-based instruction and how it has been put into practice at the Wylie House Museum.

The university's first campus archaeology field school was held on museum property during the summer of 2018. Prior to excavating on site, students from X480: Fieldwork in Archaeology

were introduced to the materials in the collection that indicated the presence of $19^{\text {th }}$ century subterranean greenhouses used by the Wylie family. They evaluated the artifacts, made hypotheses and embarked upon additional research to inform the location and historical context related to their dig. Embedded in the course learning objectives was the expectation that students would be able to articulate or demonstrate historic relevance to their field school experience. Students accomplished this in a variety of ways, most often through presenting an overview of their research and fieldwork to others. Some worked on creating exhibits, some led tours to visitors, and others gave public presentations. The majority of students in the course noted a positive emotional connection or enhanced meaning to their learning experience through these assignments. For example, senior field school student, Hannah, stated, "I especially liked knowing that women involved in early IU [Indiana University] had their hands in this dirt, just like me. Since we read their letters I could almost hear them, and now our class is part of history too." 16

This archaeology field school course developed as part of a larger collaborative project between the museum and the campus' archaeology laboratory. The excavation and class held on museum grounds were made possible through university funding, with the expectation that it

\footnotetext{
${ }^{16}$ Hannah, X480 Student in post-course reflection, June 2018.
} 
could potentially serve as a model for future campus excavations. Ultimately, project leaders hope that the course will provide a model for future campus archaeology excavations and contribute to a change in university-wide campus archaeology program. By the end of the course it was the students who became campus archaeology's most vocal advocates. They participated in interviews with university and local news outlets to advocate for future campus digs. Project leaders expect that these positive student activities will support campus policy changes relative to historic archaeology.

A Department of English rhetoric class is a wonderful representation of how place-based learning can inspire complex, critical thinking and inquiry in students. Course R398: Culture, Identity, and Rhetoric of Place requires students to use primary sources (early maps, family letters, historic structure reports, and financial documents) to study the Wylie House Museum as a historic structure which informs and is informed by multiple family members, construction workers involved in the 1960s reconstruction of the home, and preservation experts. Students research historical context and evaluate building and restoration decisions made in the 1830s and 1960s. After researching the Wylie House one of the students said, "The class and the museum made me wonder about other buildings and decisions about them when I walk through campus." ${ }^{17}$ His feedback is typical of the students in this course. Students begin to inquire about campus planning, the origins of building names, and individuals behind them. These experiences often change their relationship to the university and its history.

\footnotetext{
17 Jesse, R398 student, in course reflection, April 2017.
} 
Course instructor, Cindy Smith, $\mathrm{PhD}$. collaborated with the museum director to capitalize on the benefits of place-based learning after they found themselves discussing the perceived significance to bringing her students to the museum. According to Smith,

It is very important to me to anchor what my students are learning about space and architecture to a tangible, local example. Visiting the museum helps students experience the place with all of their senses. Doing so helps them think more critically about changes in architecture through time and the challenges that this creates in interpretation for house museums (real life application). The best possible way to help students make those kinds of connections is by "being in the place." 18

\section{IU Archives - SoAD S485/S582 Metalsmithing and Jewelry Design, Fall 2016 - Spring 2017}

The University Archives is the official repository of University administrative records, as well faculty papers and materials documenting the student experience. Inspired by the recent acquisition of the papers of Alma Eikerman, an innovative metalsmith, jewelry designer, and professor and founder of the jewelry program at Indiana University, in 2016 the IU Archives paired up with two professors in the metalsmithing and jewelry design area at IU. Seeking to design an assignment relevant to the life of their students, according to Professor Nicole Jacquard it was important that the students in the course understand that they were part of a multi-generational lineage of artists tracing their roots back to Eikerman.

During the first semester, the twelve students were given two assignments. First, they were simply assigned to write a research paper using a section of the collection. For example, one student looked at Eikerman's travel documentation, another research notes, another

\footnotetext{
${ }^{18}$ Cindy Smith, Email to the author, April 24, 2018.
} 
correspondence, another her teaching files, another her photographs, another her sketchbooks, etcetera. Then, they were each assigned to design two pieces of jewelry or hollowware inspired by something they found in the collection. Ultimately, the students were so excited with what they were finding and creating that they wanted to share it with a wider audience. They submitted a proposal to the local arts center, and the exhibit Lineage as Legacy opened in April 2017.

The students drew inspiration form the Eikerman collection in numerous ways. Some choose to experiment with new techniques that she pioneered and were documented in her records, others were influenced by her style. Others were inspired by the personal stories found in her papers. For example, then $2^{\text {nd }}$ year MFA student Heather Nuber was inspired by the gender wage-gap issues Eikerman faced as a female faculty member in a male-dominated department. In her exhibit label for Little Pieces, she noted that:

Alma Eikerman created statement pieces from simple form and line. She was formidable, but I can imagine she had to be. A single woman, in a male driven field, in male-dominated academia, formidable survives. Although she was a leading force in her field, she fought for decades for equitable pay. Putting myself in her place, I think of all the times she had to smile through back-handed compliments of her "little pieces," as her male counterparts doing "serious" work continued to earn more. I think about her taking all of that frustration out on the metal, and bending it to her will, creating her incredibly influential "little pieces."19

\footnotetext{
${ }^{19}$ NUBER Heather, exhibit label for Little Pieces from the exhibit Lineage as Legacy, April 2017.
} 
Near the entrance, an electronic monitor rotated through archival photographs of Alma Eikerman. On a nearby wall, a "family tree" beginning with Eikerman documented the multi-generational lineage of the student artists represented in the exhibit and according to Jacquard "how they are now a part of our family and enduring lineage and legacy."20

In retrospect, the collaboration was successful from multiple perspectives. For the professors, it was " "one of the best learning experiences the students ever had." Jaquard noted that "I truly believe it gave them a deep sense of place and pride knowing the history that they are now a part of." ${ }^{21}$ The process clearly inspired the students, one noted that she usually did not do research before starting on a new artwork, “"the personal relationship of Alma's archives and her connection to IU made the process more interesting." 22 For the IU Archives, the collaboration furthered our teaching mission to reach students with primary sources in an authentic way and brought this collection to a wider community audience.

\section{Conclusion}

For archivists teaching with local collections, it is likely that instinctually they already understand the potential power that these materials hold for students and are regularly attempting to harness it in our classrooms. There are many advantages to Place-based education. It has the potential to create inspired inquiry and more meaningful learning; however, there are also valid critiques. There are numerous pedagogical approaches and teaching methods, and in order to reach our students it is important to also remember that place-based learning is merely one tool

\footnotetext{
${ }^{20}$ JACQUARD Nicole quoted in BARCLAY-MORTON Julia Lee, “IU Professor's Archives Inspire CrossDiscipline Projects" in Library Journal, August 23, 2017, at https://lj.libraryjournal.com/2017/08/academiclibraries/iu-professors-archives-inspire-cross-discipline-projects/\#_.

21 Randy Long quoted in Barclay-Morton, "IU Professor's Archives Inspire Cross-Discipline Projects".

${ }^{22}$ Angela Caldwell quoted in Barclay-Morton, "IU Professor's Archives Inspire Cross-Discipline Projects”.
} 
to add to the educational toolbox. When appropriate, it can be a strong frame for archival instruction in higher education. 